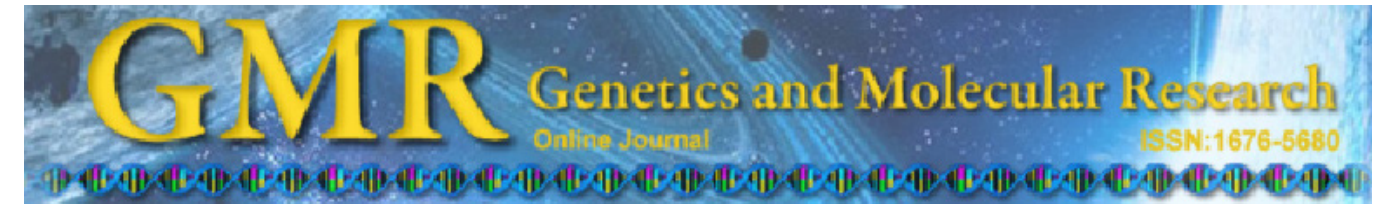

\title{
Comparative in vitro and in planta analyses of extracellular enzymes secreted by the pathogenic fungus Sclerotinia sclerotiorum
}

\author{
M.B. Oliveira, S.C. Barbosa and S. Petrofeza \\ Instituto de Ciências Biológicas, Universidade Federal de Goiás, \\ Goiânia, GO, Brasil \\ Corresponding author: S. Petrofeza \\ E-mail: petrofez@uol.com.br
}

Genet. Mol. Res. 12 (2): 1796-1807 (2013)

Received October 2, 2012

Accepted February 20, 2013

Published June 6, 2013

DOI http://dx.doi.org/10.4238/2013.June.6.3

\begin{abstract}
Dry bean (Phaseolus vulgaris L.) is an important economic crop in Brazil but its yield can be significantly reduced by white mold, a disease caused by Sclerotinia sclerotiorum (Lib.) de Bary, a necrotrophic, highly destructive, and non-host-specific fungus. This fungus secretes numerous cell wall-degrading enzymes such as polygalacturonases, exo- $\beta$-1,3-glucanases, xylanases, and cellulases that have been detected during the early stages of infection. In this study, the activities of these enzymes were detected in all carbon sources tested (citrus pectin, cell wall extract from $P$. vulgaris, carboxymethyl cellulose, and glucose), but the highest levels were found when using citrus pectin and cell wall extract from $P$. vulgaris. Regardless of the carbon source, $\mathrm{pH}$ decreased throughout the culture time. During pathogenesis in dry bean stems, increased enzyme activities were also observed. Reverse transcriptase-polymerase chain reaction experiments showed that the induction of polygalacturonases (sspg1, sspg3, sspg5, sspg6, and sspg7), exo- $\beta-1,3$-glucanases, and endo- $\beta-1-4$-glucanase in S. sclerotiorum occurred during the early stages of colonization.
\end{abstract}

Key words: Endopolygalacturonase; Xylanases; Cellulases; White mold 


\section{INTRODUCTION}

Sclerotinia sclerotiorum (Lib.) de Bary (1886) is an important fungal plant pathogen that significantly reduces the yield and quality of agricultural crops worldwide (Purdy, 1979; Boland and Hall, 1994). Moreover, this ubiquitous ascomycete has a wide host range and can infect and damage over 400 species of plants, including field crops, vegetables, fruits, and ornamentals (Purdy, 1979; Boland and Hall, 1994). In addition to its relevance as an economically important phytopathogen, $S$. sclerotiorum and its hosts are a convenient model to study the physiological and molecular bases of plant-pathogen interaction.

Enzymatic degradation of plant cell wall polymers and tissue maceration are important aspects of the pathogenesis of S. sclerotiorum, a widespread necrotrophic pathogen. During interaction with its host, S. sclerotiorum secretes oxalic acid (Noyes and Hancock, 1981; Marciano et al., 1983; Magro et al., 1984; Cessna et al., 2000; Billon-Grand et al., 2012) and multiple lytic enzymes - pectinases, $\beta$-1,3-glucanases, glucosidases, cellulases, xylanases, and proteases - that facilitate penetration, colonization, and maceration of plant tissues to generate assimilable nutrients for fungal growth (Marciano et al., 1983; Godoy et al., 1990; Cessna et al., 2000). A wide range of activities are attributed to these enzymes, from enzymatic cleavage of structural host cell wall polysaccharides, in which the integrity of the cell wall barrier to pathogen entry is compromised, to more complex roles within the sphere of host-pathogen interactions, such as the release of oligosaccharides that function as elicitors of plant defense responses (Cooper, 1983; Côtè and Hahn, 1994; De Lorenzo et al., 1994, 1997).

S. sclerotiorum produces multiple hydrolytic enzymes, but studies have not yet established which of them are important pathogenicity factors or defined their specific roles during the infection process. We have previously shown that various carbon sources combined with acidification of the medium are important factors in the control of acid protease and aspartyl protease gene expression during S. sclerotiorum pathogenesis (Bueno et al., 2012). In this study, we aimed to elucidate how extracellular hydrolytic enzymes are induced during $S$. sclerotiorum pathogenesis in the dry bean Phaseolus vulgaris L. and to determine whether the mechanisms of regulation differ between in vitro and in planta models.

\section{MATERIAL AND METHODS}

\section{Organism and culture conditions}

S. sclerotiorum strain SPS was collected from a naturally infected bean plant and grown on Petri dishes containing potato dextrose agar (PDA) culture medium at $20^{\circ} \mathrm{C}$ for 5 days. Minimal salts medium $\left(2 \mathrm{~g} / \mathrm{L} \mathrm{NH}_{4} \mathrm{NO}_{3}, 1 \mathrm{~g} / \mathrm{L} \mathrm{KH}_{2} \mathrm{PO}_{4}, 0.1 \mathrm{~g} / \mathrm{L} \mathrm{MgSO}_{4} .7 \mathrm{H}_{2} \mathrm{O}, 0.5 \mathrm{~g} / \mathrm{L}\right.$ yeast extract, $3 \mathrm{~g} / \mathrm{L}$ DL-malic acid, $1 \mathrm{~g} / \mathrm{L} \mathrm{NAOH}$ ) was prepared in conical flasks containing $20 \mathrm{~mL}$ medium and inoculated with a single 3-mm mycelial plug excised from the margin of a 5-day-old colony growing on PDA and shaking at $20^{\circ} \mathrm{C}$ for $48 \mathrm{~h}$. The cultures were centrifuged at $2000 \mathrm{rpm}$, washed twice, and used as inoculum in minimal salt medium supplemented with various carbon sources - namely $1 \%$ citrus pectin, $1 \%$ cell wall extract from $P$. vulgaris $(\mathrm{CWPv}), 1 \%$ carboxymethyl cellulose $(\mathrm{CMC})$, or $1 \%$ glucose. The cultures were grown in conical flasks with constant shaking at $20^{\circ} \mathrm{C}$ for $12-96 \mathrm{~h}$. The mycelium was harvested via filtration and stored at $-80^{\circ} \mathrm{C}$ until needed for RNA extraction. Samples of the culture super- 
natants, collected daily and centrifuged at $3000 \mathrm{rpm}$ for $15 \mathrm{~min}$, were used to measure enzyme activity (polygalacturonases, $\beta$-1,3-glucanase, CMCase, and xylanases) and $\mathrm{pH}$. Total protein content was determined using a Quant-iT Protein Assay kit (Invitrogen, Carlsbad, CA, USA).

\section{Infection and bean tissue sampling}

Plants of the dry bean cultivar Pérola were grown in a greenhouse in 2-kg plastic pots filled with red-yellow latosol soil supplemented with $5 \mathrm{~g}$ 4-30-16 NPK fertilizer. The inoculation was performed 30 days after emergence via introduction of either 1) toothpick ends wrapped with the pathogen mycelia into the base of the stems $1.0 \mathrm{~cm}$ above the soil surface or 2) PDA plugs with mycelium into the axillary region of the stems. Non-infected plants were used as experimental controls. All plants were kept at $20^{\circ} \mathrm{C}$ and $90 \%$ relative humidity to provide adequate conditions for infection. Tissue samples were collected from both the necrotic part and the chlorotic area of each lesion within $2 \mathrm{~cm}$ of the lesion edges $6,12,24,48,72$, and $96 \mathrm{~h}$ post-inoculation (hpi) and immediately frozen in liquid nitrogen before RNA and protein extraction. Each treatment consisted of a pool of 10 plants from different pots.

For protein extraction, the samples collected from plants infected with S. sclerotiorum were macerated in liquid nitrogen and homogenized in $1 \mathrm{M} \mathrm{NaCl}$ and $0.1 \mathrm{M}$ sodium acetate buffer, $\mathrm{pH} 5.2\left(3 \mathrm{~mL} / \mathrm{g}\right.$ tissue). The homogenate was centrifuged at $20,000 \mathrm{~g}$ at $4^{\circ} \mathrm{C}$ for 25 $\mathrm{min}$. The supernatant obtained was considered the tissue extract and used to determine enzyme activity. Total protein content was determined using a Quant-iT Protein Assay kit (Invitrogen) according to manufacturer specifications.

\section{Determination of enzyme activity}

For all hydrolases, enzyme activity was expressed in units. One unit is equal to $1 \mu \mathrm{mol}$ of the corresponding sugar released after $1 \mathrm{~min}$ of incubation under the standard conditions. Specific activity was referred to $1 \mathrm{mg}$ protein $(\mathrm{U} / \mathrm{mg})$. Three samples were analyzed for each treatment, and enzyme and substrate controls were included in all assays.

\section{Polygalacturonases}

Polygalacturonase activity was quantified by the increase in absorbance at $575 \mathrm{~nm}$ caused by the release of reducing sugars from citrus pectin. The reaction mixture contained 25 $\mu \mathrm{L}$ macerated tissue extract or culture supernatant and $225 \mu \mathrm{L} 2 \mathrm{mg} / \mathrm{mL}$ citrus pectin (SigmaAldrich, St. Louis, MO, USA) dissolved in $0.1 \mathrm{M}$ sodium acetate buffer, $\mathrm{pH}$ 5.0. After incubation at $50^{\circ} \mathrm{C}$ for $30 \mathrm{~min}$, the reaction was stopped by adding $750 \mu \mathrm{L}$ 3,5-dinitrosalicylic acid (DNS) reagent, boiled for $5 \mathrm{~min}$, and cooled on ice (Miller, 1959).

\section{$\beta-1,3-g l u c a n a s e$}

$\beta$-1,3-glucanase activity was assayed using commercial laminarin (Sigma-Aldrich) as the substrate. The reaction medium consisted of $0.05 \mathrm{~mL}$ supernatant and $0.1 \mathrm{~mL}$ substrate solution $\left(0.25 \%\right.$ laminarin solution in $50 \mathrm{mM}$ acetate buffer, $\mathrm{pH}$ 5.2). After incubation at $50^{\circ} \mathrm{C}$ for $30 \mathrm{~min}$, the concentration of reducing sugars was determined using the DNS method (Miller, 1959). 


\section{CMCase}

CMCase activity was determined by measuring the release of reducing sugars during CMC degradation (Sigma-Aldrich). The reaction medium consisted of $0.5 \mathrm{~mL} \mathrm{1 \% (w/v)} \mathrm{CMC}$ solution in $50 \mathrm{mM}$ sodium citrate buffer, $\mathrm{pH} 5.2$, and $0.5 \mathrm{~mL}$ supernatant. After incubation at $50^{\circ} \mathrm{C}$ under agitation for $30 \mathrm{~min}$ to ensure sugar release at a constant rate, an aliquot of $0.5 \mathrm{~mL}$ was removed and immediately transferred to tubes containing $0.5 \mathrm{~mL}$ DNS, which interrupted the enzymatic reaction and allowed the quantification of reducing sugars (Miller, 1959).

\section{Xylanases}

Xylanase activity was based on the production of reducing sugars from polymeric 4-O-methyl-glucuronoxylan (Sigma-Aldrich). The reaction medium consisted of $1 \%$ xylan in $0.1 \mathrm{M}$ sodium acetate buffer, $\mathrm{pH} 5.0$, plus the appropriate amount of enzyme to a final volume of $125 \mu \mathrm{L}$. After incubation at $35^{\circ} \mathrm{C}$ for $10 \mathrm{~min}$, the reaction was interrupted by adding 187.5 $\mu \mathrm{L}$ DNS solution used to assay reducing sugars (Miller, 1959) and incubated again for $5 \mathrm{~min}$ in a boiling water bath.

\section{Semi-quantitative reverse transcription-polymerase chain reaction (PCR)}

RNA was extracted from plant tissue and fungal material using the standard Trizol protocol (Invitrogen). To remove any genomic DNA contamination, we treated the RNA with RNAse-free-DNAse I (Invitrogen) followed by enzyme inactivation ( $2.5 \mathrm{mM}$ ethylenediaminetetraacetic acid, $65^{\circ} \mathrm{C}, 10 \mathrm{~min}$ ) and ethanol precipitation.

The transcriptional analyses of fungal genes were carried out using semi-quantitative reverse transcription-PCR and specific oligonucleotide primers (Table 1). 28S ribosomal DNA gene-specific primers were designed according to the $28 \mathrm{~S}$ ribosomal DNA gene of S. sclerotiorum and used to amplify a 617-bp cDNA product that acted as a control in reverse transcription-PCR experiments.

\begin{tabular}{|c|c|c|c|c|}
\hline Gene & Hypothetical function & ID & Primer sequence $\left(5^{\prime}-3^{\prime}\right)$ & Product size (bp) \\
\hline $\operatorname{sspgl} 1$ & Endopolygalacturonase & L1202 & $\begin{array}{l}\text { F: TCTTGCAGCAGTCGAGAAG } \\
\text { R: GTGTTGTGTCCGAGGGAGT }\end{array}$ & 495 \\
\hline $\operatorname{sspg} 3$ & Endopolygalacturonase & Ay312510 & $\begin{array}{l}\text { F: ACCCACCACTTTGGCTACTG } \\
\text { R: TGAGACGGTAAGACCCTTG }\end{array}$ & 448 \\
\hline $\operatorname{sspg} 5$ & Endopolygalacturonase & CD646235 & $\begin{array}{l}\text { F: TGTCCAAGTTTTCAGTATT } \\
\text { R: CTACCAGCATTTCCATTAT }\end{array}$ & 452 \\
\hline sspg6 & Endopolygalacturonase & CD645962 & $\begin{array}{l}\text { F: AAGCTTATTGGAATGGGTAT } \\
\text { R: CTGGAGTTGACGATTTGACTA }\end{array}$ & 462 \\
\hline $\operatorname{sspg} 7$ & Endopolygalacturonase & CD645693 & $\begin{array}{l}\text { F: TCCGGTTACGAGGATGTTA } \\
\text { R: GCTCCTGGACACGTCATT }\end{array}$ & 380 \\
\hline$\beta-1,3$ & Exo- $\beta$-1,3-glucanase & SS1G_060371 & $\begin{array}{l}\text { F: ACCCCGATACTGCTGTTGTC } \\
\text { R: TGCCTCCATGAAATATGCAA }\end{array}$ & 404 \\
\hline$\beta-1,4$ & Endo- $\beta-1-4$-glucanase & SS1G_00458 & $\begin{array}{l}\text { F: CAAGGCAGCTTAACCGCTAC } \\
\text { R: GATCCATCGGAGTCGAGGTA }\end{array}$ & 452 \\
\hline Oxalo & Oxaloacetate acetylhydrolase & DV643703 & $\begin{array}{l}\text { F: CCCAATCGTCGAGGACAAGC } \\
\text { R: TGCCTGCTCCGGTCATGTAA }\end{array}$ & 334 \\
\hline rDNA & $28 \mathrm{~S}$ & - & $\begin{array}{l}\text { F: TCCGGTTACGAGGATGTTA } \\
\text { R: GCTCCTGGACACGTCATT }\end{array}$ & 617 \\
\hline
\end{tabular}

$\mathrm{ID}=$ identification; $\mathrm{F}=$ forward primer; $\mathrm{R}=$ reverse primer. 
First-strand cDNA was synthesized using $1 \mu \mathrm{g}$ DNAse-treated total RNA and Superscript II Reverse Transcriptase (Invitrogen) following supplier recommendations. For the amplification, $5 \mu \mathrm{L}$ first-strand cDNA was used in a final reaction volume of $25 \mu \mathrm{L}$ containing $1 \mathrm{X}$ Taq DNA polymerase buffer, $1.5 \mathrm{mM} \mathrm{MgCl}_{2}, 0.2 \mathrm{mM}$ deoxyribonucleotide triphosphate, $0.2 \mu \mathrm{M}$ specific primers, and $5 \mathrm{U}$ Taq DNA polymerase (Invitrogen). PCR was initially performed at $94^{\circ} \mathrm{C}$ for $4 \mathrm{~min}$, and then 27 cycles as follows: $94^{\circ} \mathrm{C}$ for $1 \mathrm{~min}, 55^{\circ} \mathrm{C}$ for $1 \mathrm{~min}$, and $72^{\circ} \mathrm{C}$ for $1 \mathrm{~min}$. PCR products were resolved with electrophoresis on a $1.2 \%(\mathrm{w} / \mathrm{v})$ agarose gel (Sambrook et al., 1989). Two replicates of the reverse transcription-PCR experiments were performed for all genes analyzed.

\section{Statistical analysis}

Analysis of variance and the Tukey test were applied to detect significant differences $(\mathrm{P}<0.05)$ in enzyme activity among the supernatants from different growth media and among different infection times.

\section{RESULTS AND DISCUSSION}

\section{Characterization of enzyme activity of $S$. sclerotiorum using various carbon sources}

To know whether polygalacturonase, cellulases, and xylanases are continuously produced by $S$. sclerotiorum in inducing cultures (citrus pectin, CWPv, CMC, or glucose), the culture supernatant collected between 12 and $96 \mathrm{~h}$ was analyzed. This period corresponds to 2 phases of growth: an initial phase with carbon source consumption (12-24 h after transference) and a later phase when carbon sources have been exhausted ( $96 \mathrm{~h}$ after transference).

The influence of carbon sources on fungus growth and enzyme activity was also examined. Although comparable fungus growth was observed between treatments (data not shown), citrus pectin was by large the preferred carbon substrate for enzyme production (Figure 1). Substitution of citrus pectin, CWPv, or CMC with glucose resulted in poor fungus growth and 7-, 5-, and 4-fold reductions in enzyme activity compared with citrus pectin, CWPv, and $\mathrm{CMC}$, respectively.

Time-course measurements of hydrolytic enzyme production revealed that the maximum activity levels were reached 48-72 $\mathrm{h}$ after transference to the media supplemented with citrus pectin, CWPv, or CMC (see Figure 1). The highest polygalacturonase-specific activities were observed with $700 \mathrm{U} / \mathrm{mg}$ citrus pectin and $500 \mathrm{U} / \mathrm{mg}$ CWPv. No significant levels of polygalacturonase-specific activity were found in the presence of $100 \mathrm{U} / \mathrm{mg}$ glucose (Figure 1A). In general, polygalacturonases are induced by citrus pectin, polygalacturonic acid, and metabolic end-products structurally related to the substrate; conversely, they are repressed by the presence of carbon catabolites such as glucose (Li et al., 2004).

Production of endoglucanases (CMCase and $\beta-1,3$-glucanase) was similar to that observed for total cellulase production. On an average, cultures supplied with CWPv and CMC reached maximum activity $24 \mathrm{~h}$ after transference, whereas those supplied with citrus pectin reached maximum activity $72 \mathrm{~h}$ after transference (Figure 1B and C). Xylanase-specific activity was higher in the early stages (12-24 h after transference) in cultures supplied with CWPv 
and CMC (Figure 1D). In cultures supplied with citrus pectin, a positive effect was observed $72 \mathrm{~h}$ after transference. Fungus growth $12-96 \mathrm{~h}$ after transference to potential inducers of cellulolytic activity, such as CWPv, resulted in enzyme activity corresponding to $30-50 \%$ of that obtained for CMC. The present results showed low but significant activity when the fungus was grown on glucose as the main carbon source.

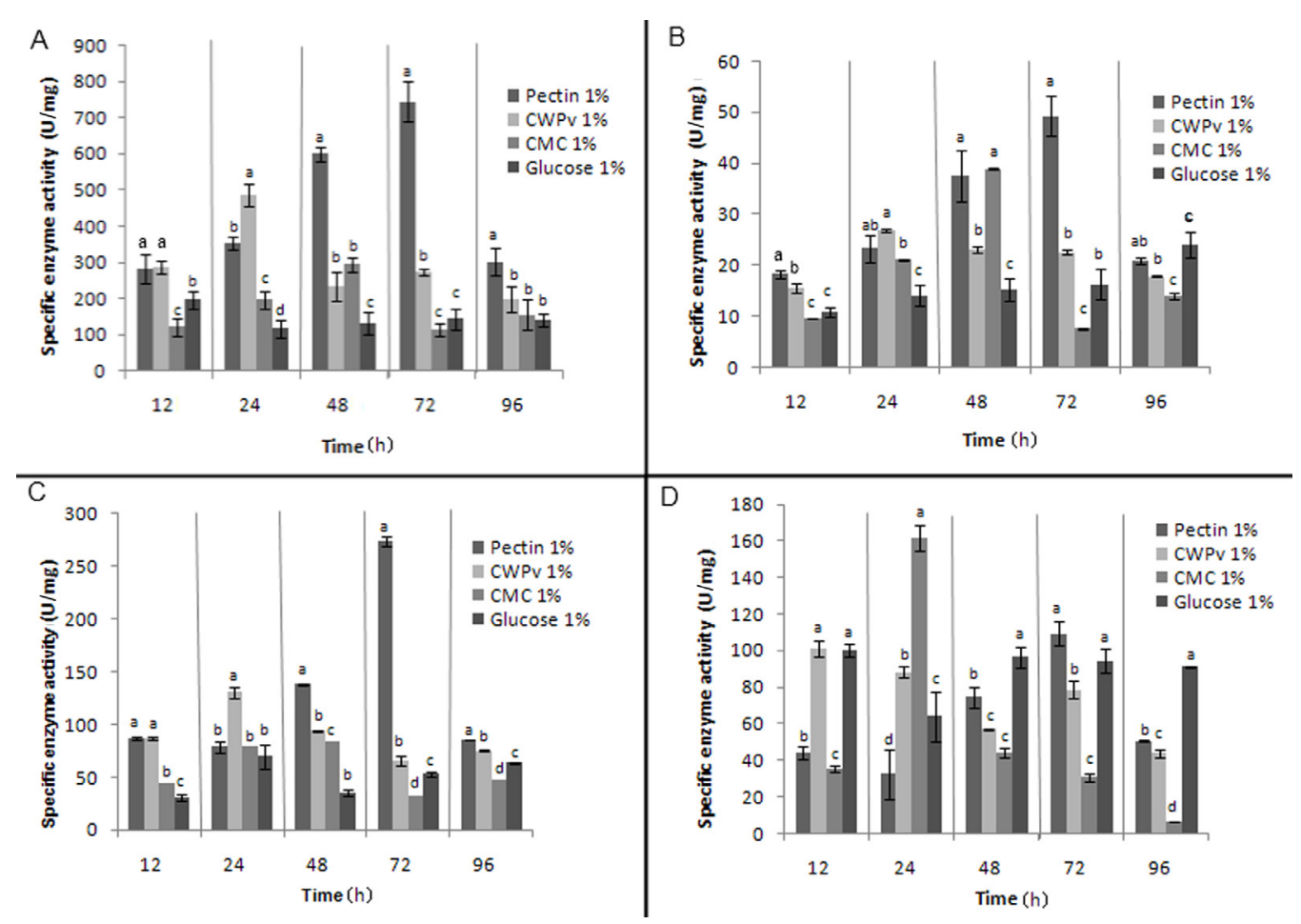

Figure 1. Enzymatic activity of culture supernatant collected after induction of Sclerotinia sclerotiorum in minimal salt medium supplemented with different carbon sources: $1 \%$ citrus pectin, $1 \%$ cell wall extract from Phaseolus vulgaris $(\mathrm{CWPv}), 1 \%$ carboxymethyl cellulose $(\mathrm{CMC})$, or $1 \%$ glucose. The tests were performed with substrate for (A) polygalacturonase, (B) CMCase, (C) $\beta$-1,3-glucanase, and (D) xylanase as demonstrated in Material and Methods. The tests were performed in triplicate and results are reported as units of activity per miligram of protein $(\mathrm{U} / \mathrm{mg})$. Three samples were analyzed for each treatment and values are means $\pm \mathrm{SD}$. Different letters on bars indicate statistical significance at $5 \%$ probability $(\mathrm{P}<0.05)$.

In these controlled culture media, a $\mathrm{pH}$ decrease was confirmed, as previously reported for Sclerotinia (Cessna et al., 2000; Rollins and Dickman, 2001; Billon-Grand et al., 2012; Bueno et al., 2012). The initial $\mathrm{pH}$ of the inoculated media was adjusted to 5.0, and a rapid decline in $\mathrm{pH}$ was observed $72-96 \mathrm{~h}$ after transfer in all treatments (4.0-2.8; Figure 2). The culture supplemented with citrus pectin presented the highest acidification (2.8; Figure 2$)$. The acidification of the culture medium likely occurred owing to the secretion of oxalic acid, an important factor in S. sclerotiorum pathogenesis (Noyes and Hancock, 1981; Marciano et al., 1983; Magro et al., 1984; Godoy et al., 1990; Cessna et al., 2000; Rollins and Dickman, 
2001; Billon-Grand et al., 2012; Bueno et al., 2012). Oxalic acid produced by S. sclerotiorum has been suggested to control the spatial pattern of cell wall-degrading enzyme production during pathogenesis (Marciano et al., 1983; Godoy et al., 1990).

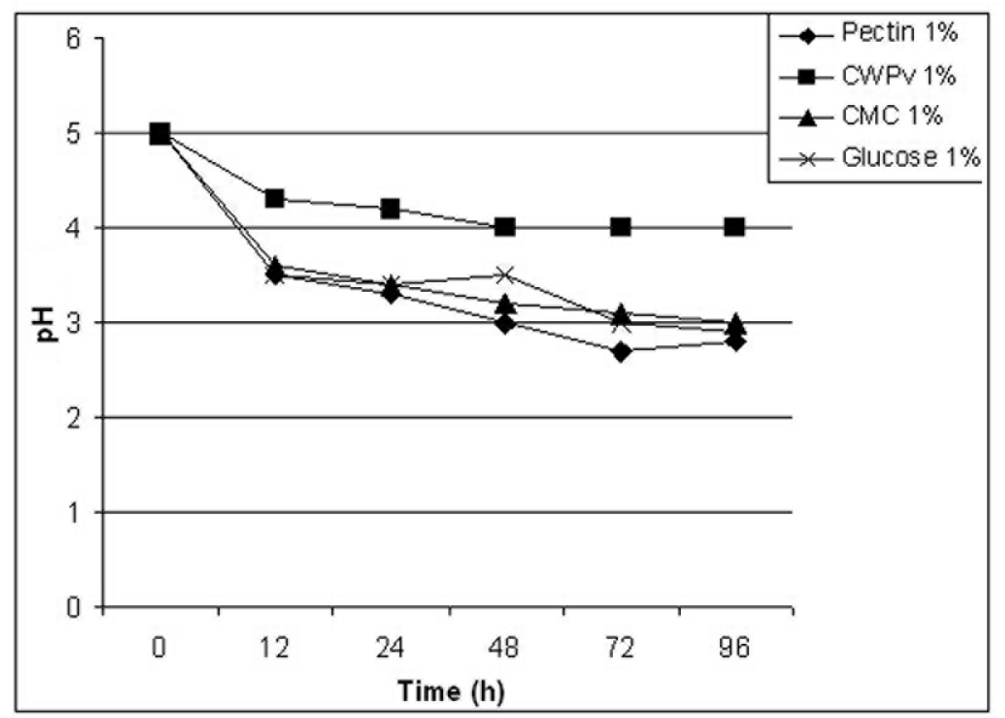

Figure 2. $\mathrm{pH}$ profiles throughout Sclerotinia sclerotiorum growth using $1 \%$ citrus pectin, $1 \%$ cell wall extract from Phaseolus vulgaris (CWPv), $1 \%$ carboxymethyl cellulose (CMC), or $1 \%$ glucose as carbon sources. At different intervals, cultures were filtered and used to determine $\mathrm{pH}$ as described in Material and Methods.

\section{Activity of enzymes secreted by $S$. sclerotiorum during $P$. vulgaris infection}

Enzyme production in planta may greatly differ from in vitro expression because some inducing factors that are present in plant tissues are absent in synthetic media (Annis and Goodwin, 1997). To investigate whether the increase in polygalacturonase, CMCase, $\beta-1,3-$ glucanase, and xylanase activity was an event that also occurred during in vivo infection, we analyzed this activity during early and late infection of $P$. vulgaris plants with $S$. sclerotiorum. We used the toothpick method of inoculation or a plug of S. sclerotiorum PDA culture (Figure 3). Plants were inspected for symptoms, and tissues showing comparable levels of damage were collected from several plants each day.

For comparison, levels of these lytic activities in tissue from infected plants or in equivalent tissues of non-inoculated plants were measured. In all the periods studied $(6,12$, $24,48,72$, and $96 \mathrm{hpi}$ ), polygalacturonase, CMCase, $\beta$-1,3-glucanase, and xylanase showed increased activity compared to control plants (non-infected). By contrast, low levels of these enzyme activities were detected in plant tissue from non-inoculated plants (Figure 4).

The lytic activities in plant tissue infected with $S$. sclerotiorum were differentially induced using the toothpick method of inoculation (infect plant-wounding) or using a plug of $S$. sclerotiorum PDA culture (infect plant; see Figure 4). Polygalacturonase and CMCase activity showed an increase up to 48 hpi only in plant tissue infected via the toothpick method (Figure 4A 
and 4B). Also, $\beta$-1,3-glucanase and xylanase activity in infected areas of the plants inoculated via the toothpick method appeared as early as 6 hpi with a moderate increase throughout, reaching a maximum after $48 \mathrm{hpi}$; thereafter, it decreased without returning to basal levels (Figure $4 \mathrm{C}$ and D). However, tissue from plants infected using a plug of S. sclerotiorum PDA culture invariably showed a level of lytic activity in the early stage of infection (6-12 hpi) that was much higher than that in plants infected using the toothpick method or that in healthy plants (see Figure 4).

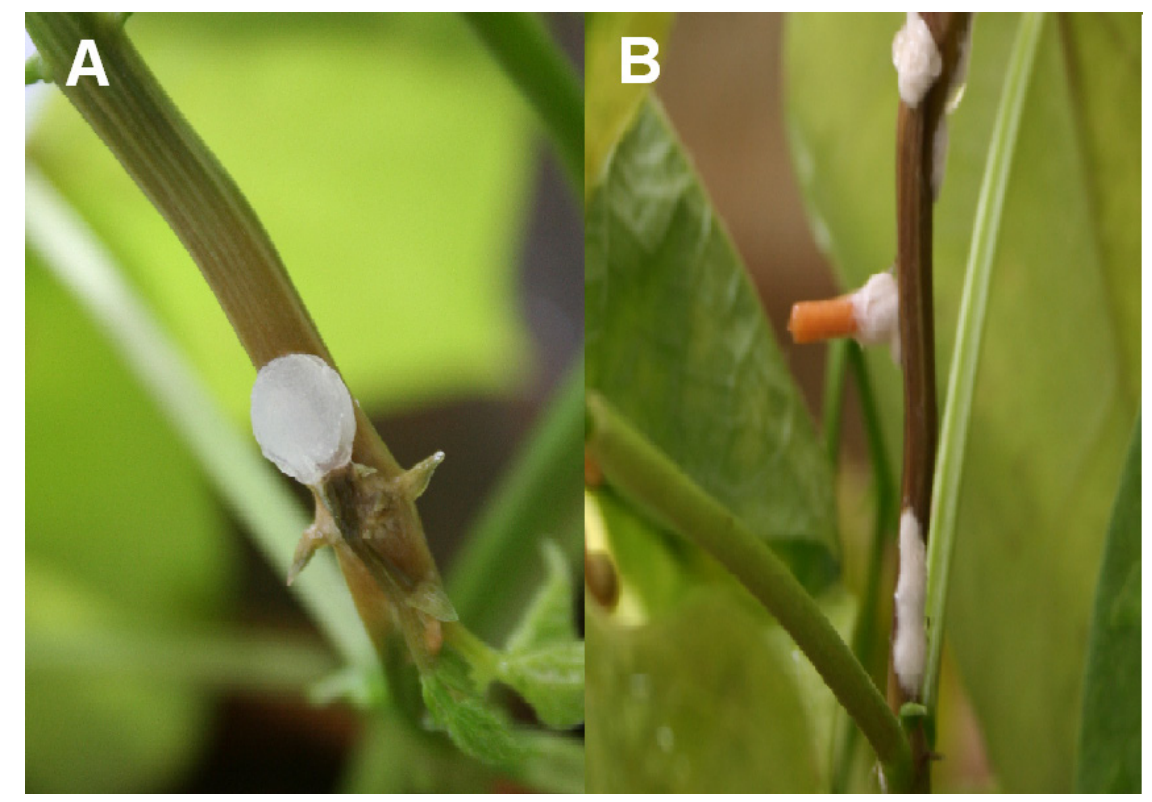

Figure 3. Comparison of method of Sclerotinia sclerotiorum inoculation in Phaseolus vulgaris L. Plant disease symptoms observed at $96 \mathrm{~h}$ post-inoculation on stems inoculated using (A) a plug of S. sclerotiorum potato dextrose agar culture and (B) toothpick method, as described in Material and Methods.

For comparison, lytic activity in healthy tissue from infected plants was also measured. Our results (data not shown) demonstrated that during infection, lytic activities are expressed only in the plant area damaged by the fungus and not in adjacent healthy tissue, thus supporting the role of these hydrolases in the localized destruction of tissue. Although restriction of these lytic enzymes to infected areas and the induction of these enzymes by plant tissues strongly support their fungal origin, further experiments are necessary to eliminate plants definitively as the source of some of these activities.

In the primary cell wall, the cellulose and hemicellulose networks are embedded in a gel matrix of pectic substances (Carpita and Gibeaut, 1993). Therefore, minimal contribution from pectin-degrading enzymes during pathogenesis in plants might be suspected because pectic polysaccharides constitute only a small proportion of the total polysaccharide content of $P$. vulgaris cell walls. However, the present data show that although enzyme kinetics maintained the same profile, polygalacturonases presented specific activity higher than that of the other enzymes analyzed. These results suggest that polygalacturonases may act first in such 
a way that the enzymatic depolymerization of pectin weakens the cell wall and exposes other polymers, such as cellulose and hemicellulose, increasing the accessibility of cell wall components for degradation by other enzymes, cell lysis, and plant tissue maceration (Annis and Goodwin, 1997; Lagaert et al., 2009). Conversely, pectic compounds may represent a source of energy for the pathogen that is more readily available than cellulosic or hemicellulosic polymers (Lagaert et al., 2009).

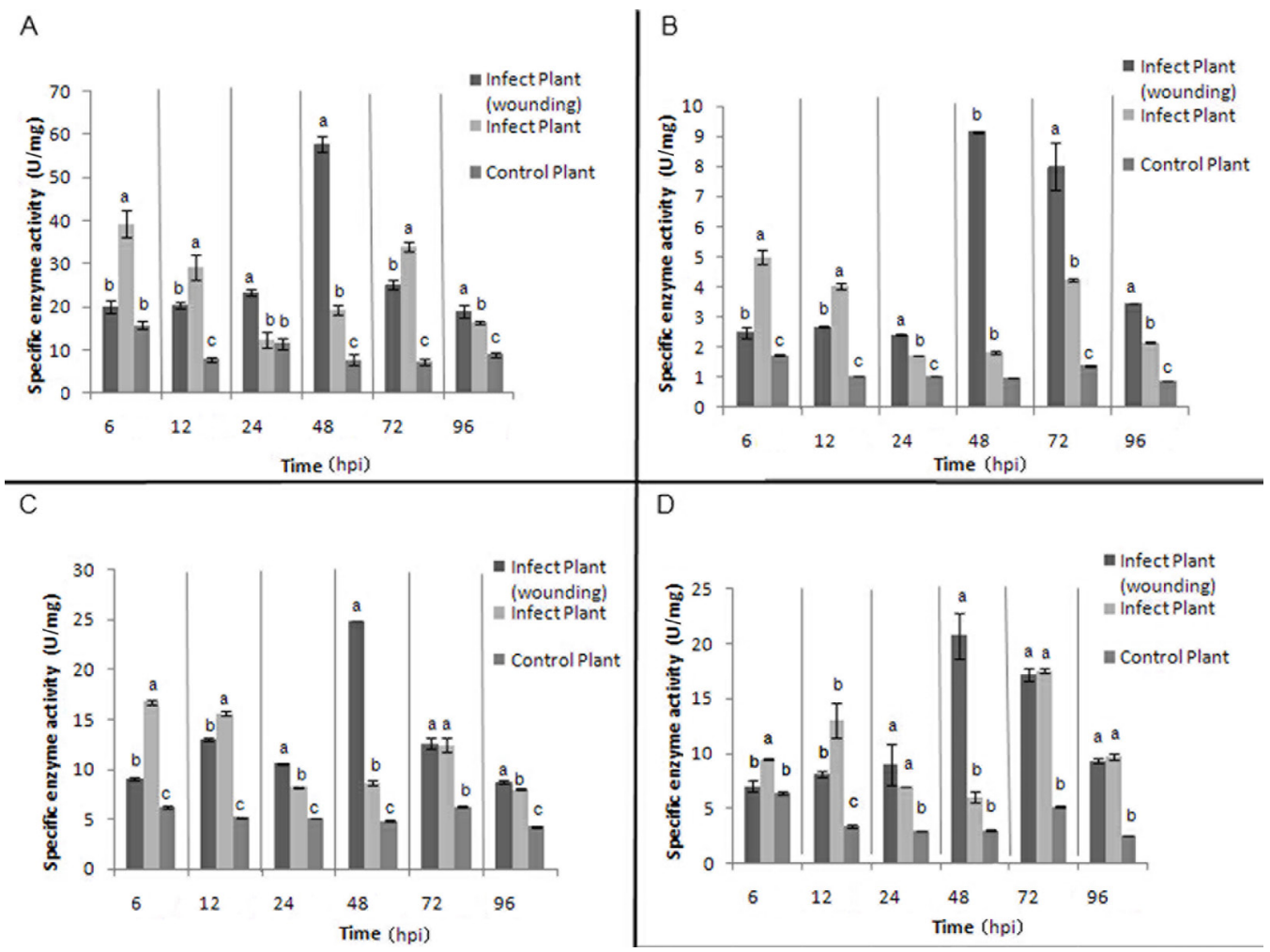

Figure 4. Activity of (A) polygalacturonases, (B) CMCase, (C) $\beta$-1,3-glucanase, and (D) xylanase. The protein extracts used in the enzyme assays were obtained from macerated stems of Phaseolus vulgaris L. plants infected with Sclerotinia sclerotiorum and non-infected plants (control) in $0.5 \mathrm{M}$ acetate buffer $\mathrm{pH} 5.0$, as described in Material and Methods. The tests were performed in triplicate and the results are reported as units of activity per miligram of protein $(\mathrm{U} / \mathrm{mg})$. hpi = hours post-infection. Three samples were analyzed for each treatment and values are means \pm SD. Different letters on bars indicate statistical significance at $5 \%$ probability $(\mathrm{P}<0.05)$.

\section{Lytic enzyme gene expression during in vitro and in planta growth of S. sclerotiorum}

The expression of polygalacturonase (sspg1, sspg3, sspg5, sspg6, and sspg7), $\beta-1,3-$ glucanase, and $\beta-1,4$-glucanase genes was analyzed during $S$. sclerotiorum cultivation in minimal salt medium supplemented with citrus pectin, CWPv, CMC, or glucose. In the cultures supplemented with citrus pectin and CMC, sspg1 and sspg7 were expressed during the whole period, whereas sspg3, sspg5, and sspg6 were highly expressed in the early stages of cultiva- 
tion, decreasing to low levels at $72 \mathrm{~h}$. The culture supplemented with $\mathrm{CWPv}$ presented variations in the pattern of expression. Expression of sspg1 and sspg3 was detected throughout the development of the fungus, whereas the other genes were not detected in any of the periods analyzed. The genes encoding $\beta$-1,3-glucanase and $\beta$-1,4-glucanase presented variations in the pattern of expression with different carbon sources or at different cultivation times (Figure 5).

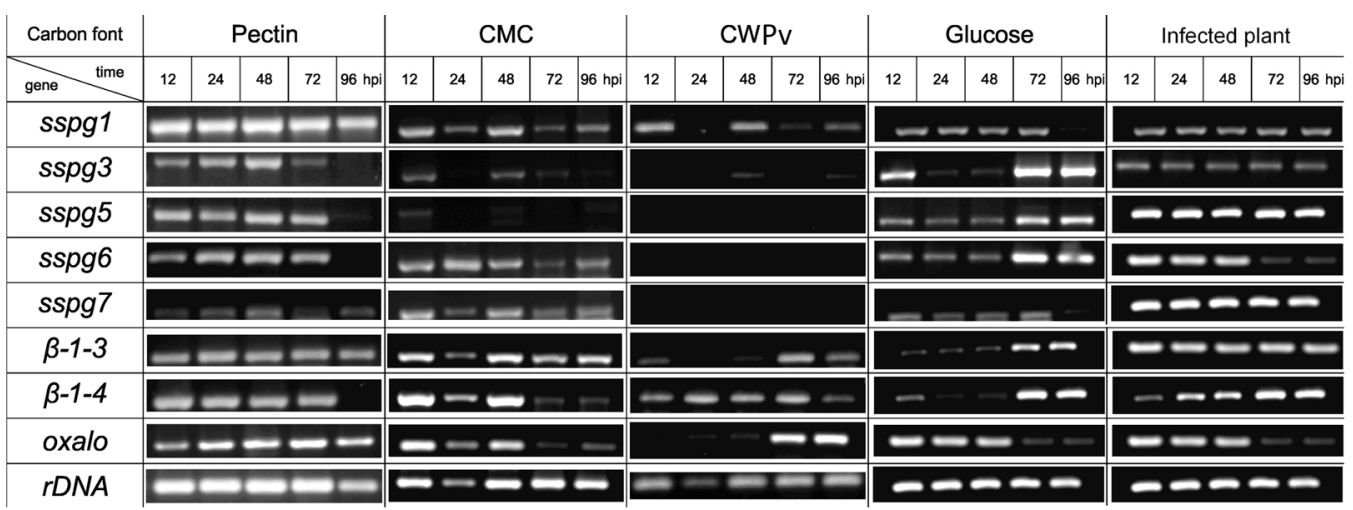

Figure 5. Temporal pattern of transcript accumulation of polygalacturonase (sspg1, sspg3, sspg5, sspg6, and sspg7) glucanase ( $\beta-1-3$ and $\beta-1-4)$, and oxaloacetate acetylhydrolase genes (oxalo) in Sclerotinia sclerotiorum mycelium grown in minimal salt medium supplemented with different carbon sources $[1 \%$ citrus pectin, $1 \%$ cell wall extract from Phaseolus vulgaris (CWPv), 1\% carboxymethyl cellulose (CMC), or $1 \%$ glucose] and a susceptible cultivar of P. vulgaris L. after inoculation with S. sclerotiorum. Ethidium bromide-stained reverse transcription-PCR products: total RNA was extracted and used in reverse transcription-PCR experiments, as described in Material and Methods. A fragment of rDNA was used to evaluate the presence of the fungus in affected tissues. hpi $=$ hours post-infection.

During infection of the $P$. vulgaris stem, the pattern of sspg expression was different from that observed in vitro: sspg1 and sspg3 were weakly expressed, sspg5 and sspg7 were highly expressed, and sspg6 displayed regulation during the later phases of infection (see Figure 5). We have previously reported similar observations (Oliveira et al., 2010). Furthermore, the $S$. sclerotiorum strain 1980 genome encodes 5 endo-polygalacturonases, 4 of which are expressed in culture or during infection (Li et al., 2004).

Early or constitutive expression of polygalacturonase activity can help establish infection and provide the pathogen with an inherent capability to release components such as galacturonic acid from plant cell walls. In turn, these substances trigger the cascade of inducible enzymes required for further destruction of host tissue and pathogen proliferation (Cotton et al., 2003). In addition, the short (10 to 12 residues) oligogalacturonides released by endopolygalacturonase and pectin lyase activity are potent elicitors of plant defense responses (Cooper, 1983; Côtè and Hahn, 1994; De Lorenzo et al., 1994, 1997).

Modulation of $\mathrm{pH}$ during infection, involving the secretion of oxalic acid, is an important mechanism in S. sclerotiorum for regulating the sequential expression of pathogenicity factors such as lytic enzymes (Rollins and Dickman, 2001; Cotton et al., 2003). In S. sclerotiorum, oxalic acid is produced from oxaloacetate in a reaction catalyzed by oxaloacetate acetylhydrolase. The expression of the oxaloacetate acetylhydrolase gene (oxalo) was analyzed in the present study to verify the probable relationship between this gene, medium $\mathrm{pH}$, 
and hydrolytic enzyme secretion. Gene expression was detected in all treatments throughout the period analyzed (see Figure 5), which was consistent with the observed decrease in $\mathrm{pH}$ (see Figure 2).

After direct penetration of host tissues, S. sclerotiorum also expressed oxalo (see Figure 4). High levels of oxaloacetate acetylhydrolase transcripts have also been detected during S. sclerotiorum vegetative growth, infection cushion development, and leaf and stem infection of Brassica napus (Sexton et al., 2006). The present results are also consistent with studies that have shown that oxalo becomes active as the infection of stems progresses and host tissue is invaded (Sexton et al., 2006). These findings suggested that S. sclerotiorum produces large amounts of oxalic acid during vegetative growth and infection to regulate developmental processes (Billon-Grand et al., 2012). In conclusion, the present data may help determine the feasibility of disabling critical enzymes as a potential disease control measure.

\section{ACKNOWLEDGMENTS}

Research supported by grants from Conselho Nacional de Desenvolvimento Científico e Tecnológico to S. Petrofeza (Proc. \#62.02553/92-4 for Biotechnology Research) and from Coordenação de Aperfeiçoamento de Pessoal de Nível Superior to M.B. Oliveira (fellow).

\section{REFERENCES}

Annis SL and Goodwin PH (1997). Recent advances in the molecular genetics of plant cell wall-degrading enzymes produced by plant pathogenic fungi. Eur. J. Plant Pathol. 103: 1-14.

Billon-Grand G, Rascle C, Droux M, Rollins JA, et al. (2012). pH modulation differs during sunflower cotyledon colonization by the two closely related necrotrophic fungi Botrytis cinerea and Sclerotinia sclerotiorum. Mol. Plant Pathol. 13: 568-578.

Boland GJ and Hall R (1994). Index of plant hosts of Sclerotinia sclerotiorum. Can. J. Plant Pathol. 16: 93-108.

Bueno EA, Oliveira MB, Andrade RV, Lobo M Jr, et al. (2012). Effect of different carbon sources on proteases secreted by the fungal pathogen Sclerotinia sclerotiorum during Phaseolus vulgaris infection. Genet. Mol. Res. 11: 2171-2181.

Carpita NC and Gibeaut DM (1993). Structural models of primary cell walls in flowering plants: consistency of molecular structure with the physical properties of the walls during growth. Plant J. 3: 1-30.

Cessna SG, Sears VE, Dickman MB and Low PS (2000). Oxalic acid, a pathogenicity factor for Sclerotinia sclerotiorum, suppresses the oxidative burst of the host plant. Plant Cell 12: 2191-2200.

Cooper MR (1983). The Mechanisms and Significance of Enzymatic Degradation of Host Cell Walls by Parasites. In: Biochemical Plant Pathology (Callow JA, ed.). John Wiley and Sons, New York, 101-135.

Côtê F and Hahn MG (1994). Oligosaccharins: structures and signal transduction. Plant Mol. Biol. 26: 1379-1411.

Cotton P, Kasza Z, Bruel C, Rascle C, et al. (2003). Ambient pH controls the expression of endopolygalacturonase genes in the necrotrophic fungus Sclerotinia sclerotiorum. FEMS Microbiol. Lett. 227: 163-169.

De Lorenzo G, Cervone F, Bellincampi D, Caprari C, et al. (1994). Polygalacturonase, PGIP and oligogalacturonides in cell-cell communication. Biochem. Soc. Trans. 22: 394-397.

De Lorenzo G, Castoria R, Bellincampi D and Cervone F (1997). Fungal Invasion Enzymes and their Inhibition. In: The Mycota: V. Plant Relationships (Carroll GC and Tudzynski P, eds.). Springer, Berlin, 61-83.

Godoy G, Steadman JR, Dickman MB and Dam R (1990). Use of mutants to demonstrate the role of oxalic acid in pathogenicity of Sclerotinia sclerotiorum on Phaseolus vulgaris. Physiol. Mol. Plant Pathol. 37: 179-191.

Lagaert S, Belien T and Volckaert G (2009). Plant cell walls: protecting the barrier from degradation by microbial enzymes. Semin. Cell Dev. Biol. 20: 1064-1073.

Li R, Rimmer R, Buchwaldt L, Sharpe AG, et al. (2004). Interaction of Sclerotinia sclerotiorum with Brassica napus: cloning and characterization of endo- and exo-polygalacturonases expressed during saprophytic and parasitic modes. Fungal Genet. Biol. 41: 754-765.

Magro P, Marciano P and Di Lenna P (1984). Oxalic acid production and its role in pathogenesis of Sclerotinia sclerotiorum. FEMS Microbiol. Lett. 24: 9-12. 
Marciano P, Di Lenna P and Magro P (1983). Oxalic acid, cell wall degrading enzymes and $\mathrm{pH}$ in pathogenesis and their significance in the virulence of two Sclerotinia sclerotiorum isolates on sunflower. Physiol. Plant Pathol. 22: 339-345.

Miller GL (1959). Use of dinitrosalicylic acid reagent for determination of reducing sugars. Anal. Chem. 31: 426-428.

Noyes RD and Hancock JG (1981). Role of oxalic acid in the Sclerotinia sclerotiorum wilt of sunflower Helianthus annuus. Physiol. Plant Pathol. 18: 123-132.

Oliveira MB, Nascimento LB, Junior ML and Petrofeza S (2010). Characterization of the dry bean polygalacturonaseinhibiting protein (PGIP) gene family during Sclerotinia sclerotiorum (Sclerotiniaceae) infection. Genet. Mol. Res. 9: 994-1004.

Purdy LH (1979). Sclerotinia sclerotiorum: history, diseases and symptomatology, host range, geographic distribution, and impact. Phytopathology 69: 875-880.

Rollins JA and Dickman MB (2001). pH signaling in Sclerotinia sclerotiorum: identification of a pacC/RIM1 homolog. Appl. Environ. Microbiol. 67: 75-81.

Sambrook J, Fritsch EF and Maniatis T (1989). Molecular Cloning: A Laboratory Manual. 2nd ed. Cold Spring Harbor Laboratory Press, New York.

Sexton AC, Cozijnsen AJ, Keniry A, Jewell E, et al. (2006). Comparison of transcription of multiple genes at three developmental stages of the plant pathogen Sclerotinia sclerotiorum. FEMS Microbiol. Lett. 258: 150-160. 